
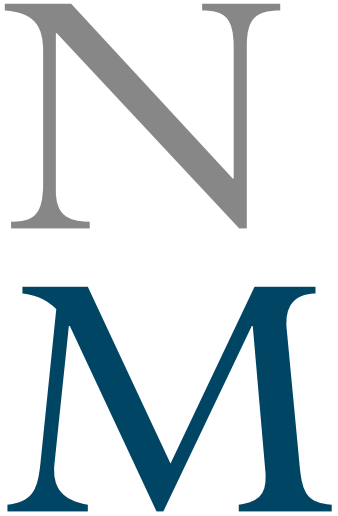
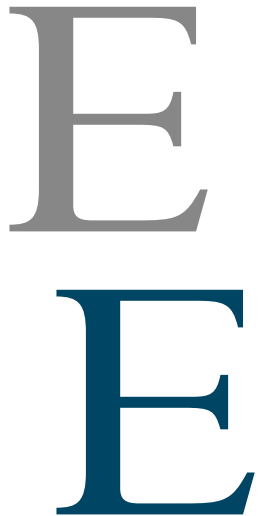
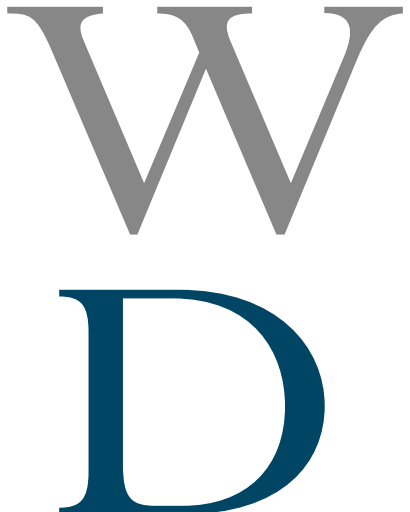
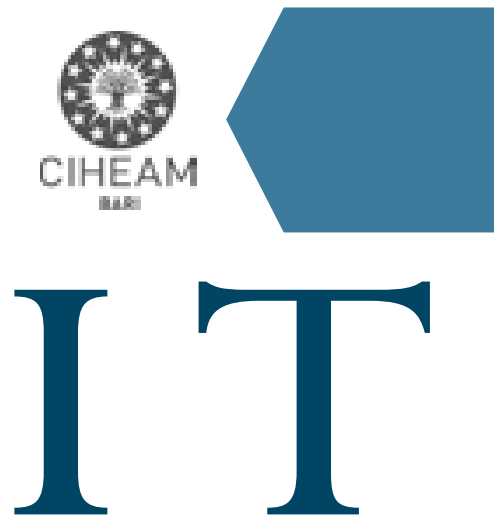

MEDITERRANEAN JOURNAL OF ECONOMICS, AGRICULTURE AND ENVIRONMENT

Poste Italiane Spa Spedizione in Abbonamento Postale Periodico ROC Centro Nord aut. $\mathrm{N}^{\circ} 0029-€ 15,00$.

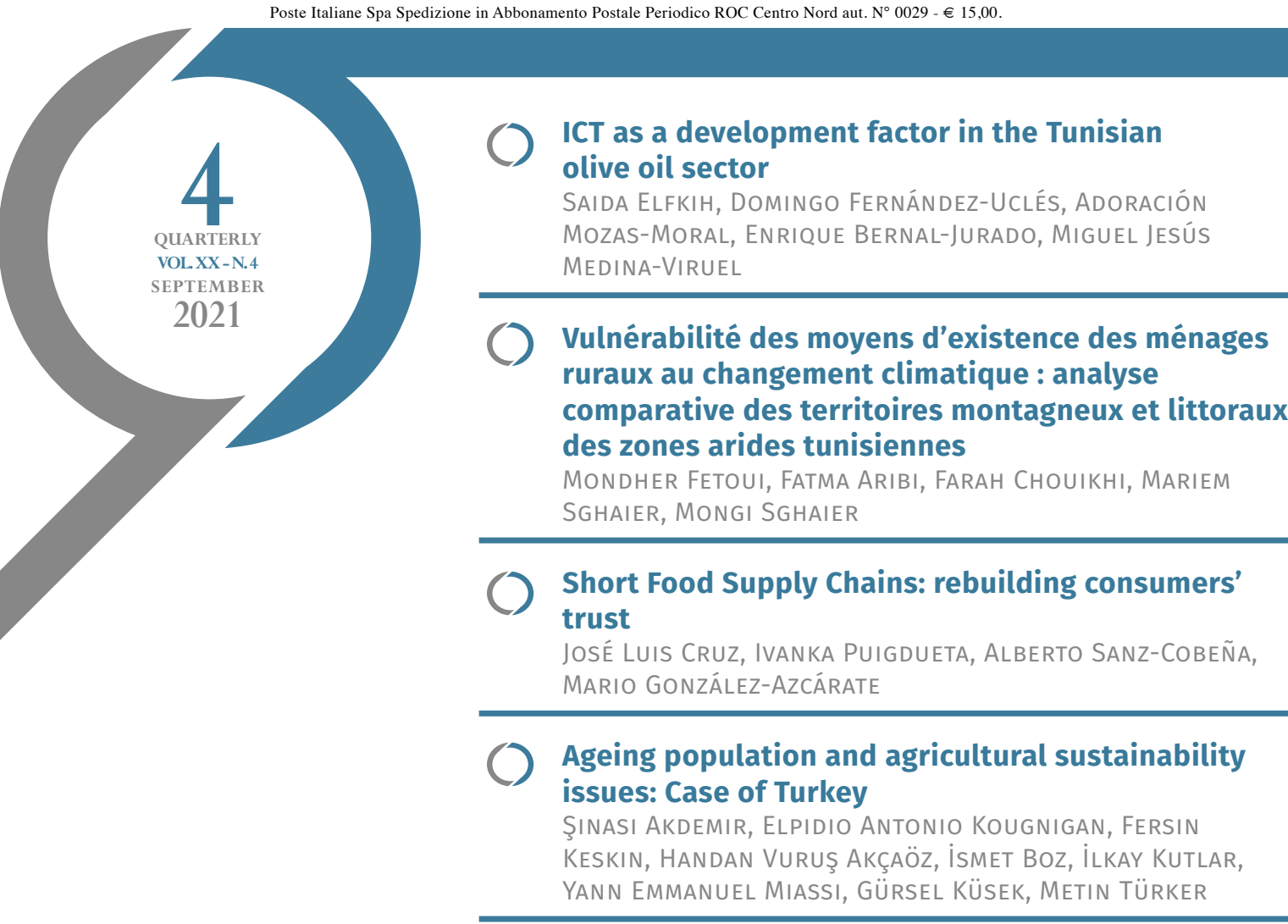




\title{
A holistic approach in explaining farmers' intentional behaviour on manure waste utilization
}

\author{
Ismail Bulent Gurbuz*, Gulay Ozkan*
}

\author{
DOI: $10.30682 / \mathrm{nm} 2104 \mathrm{~g}$ \\ JEL codes: F64, H76, Q15, Q53, R11
}

\begin{abstract}
This research examined livestock farmers' intention to move manure waste to an allocated landfill and the impact of financial support by municipalities on farmer's behaviour. The theoretical framework was developed using the Theory of Planned Behaviour and tested the validity of the model. The survey was carried out with 336 farmers in Bursa, Turkey, where animal husbandry is the primary livelihood source. Research results have shown that the developed model proved to be satisfactory in predicting farmers' intentions. The attitude $(\beta=0.38 ; p<0.01)$ variable was the most important determining factor on farmer behaviour, followed by subjective norms $(\beta=0.30 ; p<0.01)$. Local governments' financial support was a strong mediator effect between attitude $(\beta=0.62 ; p<0.01)$ and farmers 'behaviour. This study emphasizes that local governments should employ more proactive environmental measures, raise financial support initiatives in animal waste management to ensure farmers' participation in these practices and sustainable agriculture.
\end{abstract}

Keywords: Waste Management, Peri-urban farming, Theory of planned behaviour, Structured equation modelling, Environmental sustainability.

\section{Introduction}

Agricultural policies have various goals: increasing the yield, farmers' welfare, ensuring price stability, improving consumer welfare through the cheap food supply, and ensuring self-sufficiency in agriculture, rural development, and sustainable agriculture. The adverse effects of conventional agriculture on the world's environment have placed and emphasized sustainable agriculture. Sustainable agriculture ensures sustainability in livestock production. Sustainable livestock farming requires system thinking. Systems thinking takes animal production a holistic approach to animal health, welfare, breeding, nutrition, housing, and manure management as interconnected system components.

Population growth, urbanization, changing diets and rising per capita income increase the demand for meat and dairy products. The policies aimed at increasing the number of animals increased the number of livestock enterprises. Consequently, more waste was generated from enterprises. Therefore, waste, particularly manure management, is becoming increasingly critical for human and animal health. The shifting of settlements towards rural areas and

\footnotetext{
* Department of Agricultural Economics, Faculty of Agriculture, Bursa Uludag Universitesi, Nilufer/Bursa, Turkey. Corresponding author: bulent@uludag.edu.tr
} 
the inclusion of villages within the municipal boundaries, through Municipal Law 6360, increased this importance.

The Metropolitan Law No. 6360, entered into force in 2014 in Turkey, has made significant changes to local governments' administrative structure. The metropolitan municipality borders have been expanded and overlapped with the province borders (Official Gazette, 2012). Law No. 6360 resulted in converting villages in the 30 metropolitan districts to the 'neighbourhood', meaning that the people in the new neighbourhood became subject to the district and metropolitan municipality law and subject to municipal services (Koca, 2016).

The law has brought about fundamental challenges for livestock farmers. Primarily, the law required livestock farmers to obtain project and development permits and licenses to comply with minimum technical and hygienic requirements, as with all other food-dealing businesses in cities. The design and construction of the existing barns are usually done as the need arises and through experience or other farmers' advice, not within a plan and project. Manure storage is often neglected. Research shows that $80 \%$ and above of the examined livestock enterprises do not have manure storage buildings (Atilgan et al., 2005; Boyaci et al., 2011; Cayir et al., 2012). Impermeability cannot be achieved in the existing manure storage units. Manure that leaks pass into the surface runoff with precipitation mix with the surrounding surface waters and cause soil and water pollution (Cheng et al., 2015). These structures faced with the problem of obtaining licenses and obtaining these licenses brought an additional financial burden on farmers.

The authors argue that the approach to promoting environmentally friendly behaviour is tripartite through volunteerism, incentives, and regulation and that the balance between these approaches fluctuates over time. The pressure on government resources is increasing. Governments are trying to create more cost-effective agro-environmental incentives (Hodge, 2013) and are keen for farmers to turn to low-cost options arising from their voluntary activities. However, regulations remain an essential policy instrument to encourage farmers for environ- mental production. The authors stress that environmental benefits resulting from regulations require an ongoing flow of payments and compliance checks. If the support is taken out, there is a danger that those benefits will vanish (Yavuz and Gürbüz, 2001).

Numerous studies investigated farmers' willingness to accept subsidy payments for agri-environmental subsidy schemes. Some of these studies question the benefits of state support and the level of acceptance by farmers. Those authors present evidence that some farmers have been far less interested in agri-environmental subsidy schemes (AES) (Christensen et al., 2011). Authors argue that current support, particularly the environmental supports, is too low to attract most farmers (Hennessy and Wolf, 2018; Pröbstl-Haider et al., 2016). They claim that sector if farmers are willing to take up state subsidies if they are financially adequate. The main reasons for the failure of such support are inadequate compensation, excessive administrative effort, too long/too short support periods (Pröbstl-Haider et al., 2016), delayed payment (Wang et al., 2020) and farmers' unawareness of the subsidization policy.

On the contrary, many other studies have presented evidence that farmers are willing to take up state support, which is significant in farmers' behaviour. Xiong and Kong (2017) show that $87.80 \%$ of Poyang Lake Wetland farmers are willing to accept ecological compensation. Wang et al (2020) found that hog farmers revealed a strong preference for the scenario with specific and direct subsidies. Thu et al. (2019) conducted with 1287 small-scale tea producers in Vietnam. They found that the $50 \%$ price subsidy given to farmers increased their use of organic fertilizers by $25.7 \%$. Ntakirutimana et al. (2019) investigated how the local government's financial support in China's Guangxi province affects farmers' behaviour of using green manure planting. Their study showed a 1.6-fold increase in the rates of farmers' participation in green manure planting compared to farmers using rotation fallow. Pongkijvorasin and Teerasuwannajak (2019) questioned the extent to which the incentive scheme effectively reduced the highland maize production of Thai farmers in the Sopsai watershed. The incentive scheme pro- 
vided by 'Pidthong Lungpra' foundation and implemented in the Nammeed Basin in Malaysia's Nan region showed compelling results in changing farmers' highland farming behaviour.

\section{Literature review}

Efficient collection and disposal of manure waste and minimizing its effects on human and animal health and the environment requires assessing farm and livestock characteristics and considering, understanding, and analyzing farmers' attitudes, intentions and the social environment (Gurbuz and Ozkan, 2019b). There is a considerable number of research examining farmers' perceptions (Bonadonna et al., 2019; Case et al., 2017), intentions (Jiang et al., 2018), attitudes (Meena et al., 2009; Mondal et al., 2014; Simha et al., 2017; Strazzera and Statzu, 2016) and behaviour (Blackstock et al., 2010; Power et al., 2013) on various issues. One setback to these studies is that they focused on biomass waste, agricultural waste, crop waste and food and not on specifically animal waste.

The common characteristics the aforementioned studies that the effect of attitude, intention or social environment on behaviour was examined individually and independent of other factors. Many other intrinsic and extrinsic factors affect human behaviour. These factors either affect human behaviour directly besides attitudes or perceptions or indirectly by affecting attitudes and perceptions. Although the mentioned studies are precious, Ajzen's Theory Planned Behaviour (1985), which is explained in detail below, offers a more comprehensive and holistic approach in explaining farmers' intentional behaviour on the research matters; in this particular research on manure waste assessment.

\subsection{Theory of Planned Behaviour}

\section{The TPB model}

The Theory of Planned Behavior (TPB) first developed by Ajzen in 1985 and is widely used in understanding farmers' behaviour in a wide range of fields, and defines motivation and ability as the determinant of behaviour in a particular situation. TPB explains that people's conscious decisions to take specific actions are determined by their attitudes towards action, subjective norms and perceived behavioural control (Ajzen, 1985). The theory assumes that human intent has three independent determinants.

In the TPB, the main element is the individual's intention to perform a certain behaviour. Intention includes motivational factors that affect behaviour and indicate how much the individual wants to perform the behaviour. The stronger the intention, the more likely the behaviour will occur. Attitude is one of the most critical determinants of intention. Supposing that the individual has a positive attitude about doing a particular behaviour, he has a higher degree of intention about realizing that behaviour than the person who has a negative attitude. The second important determinant of intention, according to TPB is the subjective norm. Ajzen (1991) defines the subjective norm as "perceived social pressure to do or not do certain behaviour" or "other important persons' disapproval or disapproval of the individual's doing a certain behaviour". Some behaviour requires the availability of non-motivational factors such as facilities or resources (time, money, skills, etc.). TPB stresses that if an individual think that the resources and opportunities needed to realize behaviour are lacking, there will be no firm intention for that behaviour to occur. In cases where the person has control of the situation, the behaviour is estimated by the person's intention to do act in a certain way. Even if the person intends, if he cannot control his will, that behaviour may not occur. Thus perceived behaviour control (PBC) affects intention and the relationship between intention and actual behaviour (Ajzen, 2012).

\section{Extension of the TPB model}

In cases where the basic model cannot explain the behaviour, Ajzen has suggested including additional variables to the model. Therefore, some researchers have included additional variables to the original model of TPB to increase the theory's predictive power. As seen in the above examples, adding variables to the TPB model increases the model's explanatory power, but determining what these variables will be re- 
quired an in-depth analysis of the critical factors affecting farmers' behaviour.

Some authors have introduced intrinsic factors. Rezaei et al. (2018, 2019), Bagheri et al. (2019) and Maleksaeidi and Keshavarz (2019) included moral norms and knowledge variables in the original in the TPB model. They aimed to predict the factors affecting farmers' intention to engage in on-farm food safety, apply personal protective equipment, estimate farmers' intention to use pesticides, and conserve on-farm biodiversity. Wang et al. (2019) added threat appraisal (perceived severity and perceived vulnerability) and coping appraisal (self-efficacy, response efficacy, and response cost) variables in the work they analyzed the environmental behaviour of farmers about non-point source pollution control and management.

Others introduced extrinsic factors. For example, Daxini et al. (2018) examined the factors influencing farmers' intentions to adapt to nutrient management planning in Ireland. They added perceived resources variable along with farm and farmers' characteristics (e.g. age, formal education, agricultural education, discussion groups, policy, and agricultural advisor, farming systems). Their improved model predicted $90.20 \%$ of the responses (Pseudo $\mathrm{R}^{2}=0.45$ ). Chaudhary et al. (2017) examined the relationship between several variables using TPB with added variables such as personal norms, demographic factors, and past behaviours to use good irrigation practices among Florida home landscape irrigation users. $\mathrm{R}^{2}$ in the original model was 0.251 . The addition of demographic variables increased the overall $\mathrm{R}^{2}$ by $1.7 \%$. However, sociodemographic variables may not always have the same explanatory power. Meijer et al. (2015) examined the tree planting behaviour of smallholder farmers in Malawi. They also included socio-economic variables (district, gender, age, education level, membership farmers group, kinship, household size, farm labour, land size, income, and food security). However, they found that only membership of farmers groups increased $\mathrm{R}^{2}$; none of the other variables had a statistically significant effect.

Due to Turkey's social structure, almost all participants are male in studies with farmers' participation. The Majority of farmers in the country are lowly educated and have a meagre income compared to the national average. Non-Governmental Organisation membership is not widespread; farmer cooperatives have not achieved the desired efficiency. Therefore, we concluded that the inclusion of demographic characteristics would not increase the model's explanatory power, as in Meijer et al. (2015). In Turkey and all developing countries, financial problems are among the most significant issues faced by farmers. A large part of these problems is structural. Ever-changing agricultural policies, the fact that state policies primarily support industry leaves farmers in a difficult position (Gurbuz and Ozkan, 2019a).

Variability in exchange rates increases input prices, but farmers cannot reflect the cost increases on sales prices. Farmers have difficulty delivering their products directly to consumers, and small profits are collected in intermediaries' hands. The high age of the farmers and the low level of education make it difficult for them to follow technological developments. The support given to farmers is deficient compared to other industries. Furthermore, the state cannot deliver the available financial aid on time. The supports provided are for production purposes. There is no financial support to encourage farmers to adopt more sustainable behaviours or facilitate their fight against agricultural or animal waste.

The current research in the literature revealed that farmers generally view environmental applications favourably (Wang et al., 2019), but they were reluctant in implementing them due to financial constraints. We propose that farmers receive municipalities favourably allocating a specific land that does not threaten water resources and human health and provide farmers with the necessary infrastructure to dump livestock manure there safely and conveniently. Additionally, supposing that municipalities or the state provides financial incentives to cover the cost of transporting the manure to the common disposal point, in that case, farmers' behaviour towards manure's safe disposal will be positively and significantly affected.

This research hypothesis that, within the TPB framework, the financial support to be given to 
farmers to dump their livestock manure waste to an allocated area will positively affect farmers' attitudes and behaviour of farmers to establish sustainable livestock manure management. Therefore, we have developed Ajzen's basic theory by adding the financial support variable. Further, the financial support variable might have a mediatory effect on intentions well as its direct effect. We investigated the mediating effect in the third phase of the study.

The hypotheses of the research are as follows: Hypothesis 1-The TPB model created for the research will be an adequate model for explaining farmers' behavioural intentions to manage animal waste. Attitude, subjective norms, and PBC predict the behaviour of farmers regarding animal waste assessments.

Hypothesis 2-The addition of the financial support (FS) variable will increase the TPB model's explanatory power. The FS variable will positively and statistically significantly affect farmers' intentional behaviour regarding taking livestock manure waste to a central manure disposal area.

Hypothesis 3-Attitude, Subjective norms (SNs), and Perceived Behavioural Control (PBC) variables have a predictive effect on FS variable.

Hypothesis 4-The FS variable has a mediatory effect between farmers' attitude, positive norm and intentions.

\section{Methodology}

\subsection{The geographical context of the study area}

The research was carried out in Bursa province, in the town of Yenisehir. The district economy is based on agriculture and animal husbandry, and a sizeable percentage (78.7\%) of the total population makes their living from agriculture. Agricultural production is made in approximately half of the district's total area (46.4\%), and the average size of an enterprise is 32 decares. There are 32.201 animals in 2123 dairy cattle farms in the district, while there are 5.568 animals in 40 feeder cattle farms. The total number of bovines is 38 thousand. The number of ovine animal farms is 471, and there is a total of 67 thousand 344 ovines in these enterprises. Yenisehir mainly meets the meat needs of restaurants and eateries in the surrounding districts (Bursa Governorhip, 2019; YCE, 2017).

\subsection{Participants}

The target audience of the study was livestock farmers in 61 villages of Yenişehir district. As of 2017, 2123 livestock farms registered to the Farmer Registration System (FRS) in Yenişehir Province. FRS is an agricultural database developed by the Ministry of Agriculture and Livestock (MFAL). The total sample size $(n=336)$ was obtained using the formula developed by Yamane (1967) (Eq 1).

$$
n=\frac{N}{1-N e^{2}}
$$

Where $n=$ sample size; $N=$ the size of the population; = The error of 5 percentage points.

We obtained the list containing information about farms, owners and addresses registered in the FRS from District Directorate of Agriculture and Cattle Breeders Association. Sample selection made randomly in the second stage.

\subsection{Survey}

Preliminary semi-structured interviews were conducted with five agricultural farmers during February 2019. The interviews' results were analyzed; the survey was developed within the framework of a literature review and information obtained from these interviews. A panel of agricultural and environmental experts verified the facial validity. A pilot test study was performed with a final year students from the Faculty of Agriculture, and the actual research was processed between September and November 2019. The questionnaire forms were filled in one to one interviews with the farm owners. Each interview lasted about 30 to 45 minutes. Additional comments that farmers made were also noted. Besides, various observations and measurements were made on-farm structures, and detailed photographs were also taken with the farmers' permission. 


\subsection{Measurement of latent variables}

Firstly, we checked whether the scale developed to measure TPB structures meets the reliability and validity assumptions. Attitude, intention, subjective norms, and perceived behavioural control are latent constructs measured using a scale developed by Ajzen (2012). We measured each of these constructs on a scale of five items. Besides, a 4-item financial support construct was added to the TPB scale. Secondly, exploratory factor analysis (EFA) was conducted to test the construct validity, and whether the items were clustered under the correct construct was assured by checking the factor loads. Factor analysis is a widely used multivariate statistical technique that combines a large number of related variables into a small number of significant and independent factors.

Before performing EFA, a series of standard statistical tests were applied to check the suitability of the statements in the questionnaire. Kaiser Mayer Olkin (KMO) measures whether the sample is sufficient for analysis. The KMO value rages between 0 and 1 ; the closer it is to 1 , the more suitable the sample analysis is. The KMO value must be higher than 0.50 . The result of the KMO was 0.908 for the original model (TPB) and 0.915 for the developed model (TPB-FS). Bartlett's sphericity test was also significant for both models $(\mathrm{p}<0.001)$. The Bartlett sphericity test assesses the null hypothesis that the correlation matrix is the same as the identity matrix (all correlation coefficients are zero). If the $p$-value is $<0.05$, the data set is suitable for factor analysis. The Bartlett's test was significant at the $\mathrm{p}=0.0000$ level in both models. Thus, we can say that the data obtained in the study was suitable for EFA.

After achieving valid results from the tests, the EFA was carried out. We used the maximum likelihood extraction method and varimax rotation to characterize components. The eigenvalue is useful for selecting the optimal number of components that are smaller than the total number of items. The eigenvalue measures how much of the variance of the observed variables a factor explains. Any factor with an eigenvalue $\geq 1$ explains more variance than a single observed variable. Based on the above rule of thumb, four components in the TPB model and five in the TPB-FS model retained. We have preserved statements that loaded onto components above 0.3 (Hair et al., 2010). Factor loading close to -1 or 1 illustrates that the factor strongly influences the variable. In the original TPB model composed, the percentage of total variance explanation was 74,237 , while in the TPB-FS model, this ratio was 74,837 with a slight increase. Factor loads of each item ranged between 0.654 and 0.933 (Table 3).

The Cronbach alpha coefficient was calculated to ensure the internal consistency of the original model as well as the extended model and the constructs in the models within the scope of reliability and validity analysis of the conceptual model developed for the research (Nunnally, 1978). The generally accepted value is 0.70 and above. The closer coefficient value to 1 indicates the higher internal consistency of the items in the scale (Hair et al., 2010). We used SPSS software version 23 to perform EFA and descriptive statistics.

\subsection{Statistical analysis}

We used structural equality modelling (SEM) analysis with Amos software version 22.0 to validate and measure the conceptual model. We first built a structural model to investigate whether the TPB model was useful in predicting farmers' 'intentions. After validating the original model, we tested the TPB-FS model, adding the local government support construct to predict whether the support provided by local governments would influence farmers' intention to transport animal waste from their farms to a common disposal point.

We followed a=two-stage data processing approach (e.g., measurement model and structural model) following Anderson and Gerbing (1988)'s recommendation. First of all, the research measurement models were initially estimated using Confirmatory Factor Analysis (CFA) to evaluate the models' adequacy (i.e., original and extended TPB models) by assessing the model fit, convergent validity, discriminant validity, and reliability. Further, in the second stage, we used the structural equation model (SEM) to estimate the hypothesized structural relationships between constructs (Bagozzi and Yi, 1988). For this purpose, we used the survey 
Table 1 - Benchmarks and values of the model fit indicators.

\begin{tabular}{|c|c|c|c|c|}
\hline Fit Indices & Fit Indices & Good Fit & TPB Model & TPB-FS Model \\
\hline RMSEA & Root Mean Square Error of Approximation & RMSEA $<0.08$ & 0.033 & 0.014 \\
\hline NFI & Normed-Fit Index & $\mathrm{NFI} \geq 0.95$ & 0.962 & 0.975 \\
\hline NNFI & Non Normed-Fit Index & $\mathrm{NNFI} \geq 0.95$ & 0.985 & 0.997 \\
\hline CFI & Comparative Fit Index & $\mathrm{CFI} \geq 0.90$ & 0.989 & 0.997 \\
\hline SRMR & Standardized Root Mean Square Residual & SRMR $<0.08$ & 0.038 & 0.034 \\
\hline GFI & Goodness-of-fit index & $\mathrm{GFI} \geq 0.95$ & 0.947 & 0.967 \\
\hline AGFI & Adjusted Goodness-Of-Fit Index & $\mathrm{AGFI} \geq 0.90$ & 0.925 & 0.948 \\
\hline IFI & Incremental Fit Index & $\mathrm{IFI} \geq 0.90$ & 0.989 & 0.999 \\
\hline $\mathrm{N2/ \textrm {df }}$ & & $0<\mathrm{N}^{2} / \mathrm{df}<3$ & 1.415 & 1.020 \\
\hline
\end{tabular}

data variables obtained from CFA for relationship analysis after the adequacy of the measurement models was verified. SEM successfully tests complex models, performs numerous analyses at once, analyses a large number of linking constructs, and makes it easier to examine the mediation and regulatory effects and take into account measurement errors.

Many researchers have suggested several indices to test the overall fit of the models. Common threshold values less than 0.01, 0.05, 0.08 for Root Mean Square Error of Approximation (RMSEA) indicate excellent, good, and mediocre fit (MacCallum et al., 1996). CMIN/DF < 3 indicates an acceptable fit between the theoretical and data (Kline 2005). A Standardized Root Mean Square Residual (SRMR) value less than 0.10 or of 0.08 are considered a good fit Henseler et al. (2014). Goodness-of-Fit Index (GFI), Normed-Fit Index (NFI), Non Normed-Fit Index (NNFI) is higher than 0.95 and Comparative Fit Index (CFI), Adjusted Goodness-of-Fit Index (AGFI) and Incremental Fit Index (IFI) is higher than 0.90 , indicate satisfactory compliance (Kline, 2005). Those values closer to 1 represent a better fit for the proposed model. Table 1 list fit indices commonly reported for CFA and SEM.

\section{Findings}

\subsection{Descriptive Statistics}

A vast majority of the participants in our sample were 46 years and older. The average age of the farmer is 52 in Turkey (Tarmakbir, 2019).
The sample group, therefore, falls within Turkey average values. Almost half of the farmers $(41.1 \%)$ had only primary education. The average family size was around five people. About half of the farmers have 25 and fewer decares of land and small numbers of animals. Similarly, half of the farmers' income was slightly above the country's minimum income. Just over half of the farms employed only one wage worker, and two-thirds of the households were landowners, and one-third rented additional land for farming. Over $80 \%$ of the farmers have solely relied on agricultural income. The main characteristics of the respondent and farm characteristics are shown in Table 2 .

The respondents indicated their agreement with each statement with a Likert scale ranging from 1 (strongly disagree) to 5 (strongly agree) in the 3rd part of our questionnaire. The scale included a total of 24 statements, five statements to measure the attitude, SNs, PBC and intention constructs, and four statements to measure the FS construct. Table 3 shows the descriptive statistics of the TPB and TPB-FS items together with the measurement model results.

The attitude construct ranked highest among all structures in TPB and TPB-FS models. The mean AT score was 4.08 ( $\mathrm{SD}=0.755)$; considered that the highest score is 5 , farmers showed a strong positive attitude towards improving their farms' waste facilities when financial support is provided. Farmers also showed high SNs $(\mathrm{M}=3.659 \mathrm{SD}=0.575)$ and moderately $\mathrm{PBC}$ $(\mathrm{M}=2.900 \mathrm{SD}=0.498)$ in taking farm waste to a particular collection point. It has also been 
Table 2 - The demographic characteristics of the farmers and farm characteristics in $(\mathrm{N}=336)$.

\begin{tabular}{|c|c|c|c|}
\hline \multirow{2}{*}{$\frac{\text { Index }}{\text { Age }}$} & Min-Max/Relative Frequency $\%$ & Mean & $S d$ \\
\hline & $\begin{array}{l}20-35(=1) 3.3 \% \\
36-45(=2) 17.3 \% \\
46-55=3) 43.2 \% \\
56-65(=4) 31.3 \% \\
66+(=1) 5.1 \%\end{array}$ & 3.18 & 0.889 \\
\hline Education & $\begin{array}{l}\text { Literate }(=1) 0 \% \\
\text { Primary }(=2) 41.1 \% \\
\text { Secondary (=3) } 27.7 \% \\
\text { High School (=4) } 23.8 \% \\
\text { University (=5) } 7.4 \% \\
\end{array}$ & 2.98 & 0.974 \\
\hline Family Size (persons) & $\begin{array}{l}1-2(=1) 0 \% \\
3(=2) 13.4 \% \\
4=3) 20.2 \% \\
5(=4) 43.2 \% \\
6+(=5) 23.2 \%\end{array}$ & 2.76 & 0.957 \\
\hline Gross Annual Income (TL)* & $\begin{array}{l}0-50000(=1) 17.6 \% \\
50001=75000(=2) 48.2 \% \\
75001-100000(=3) 17.3 \% \\
100001-125000(=4) 11.3 \% \\
125000-150001+(=5) 5.3 \%\end{array}$ & 2.39 & 1.076 \\
\hline Non farming Income & $\begin{array}{l}\text { Yes }(=1) 19.3 \% \\
\text { No }(=2) 80.7 \%\end{array}$ & 1.81 & 0.396 \\
\hline Land Ownership & $\begin{array}{l}\text { Owner (=1) } 53.4 \% \\
\text { Rented (=2) } 22.3 \% \\
\text { Owner + Rented (=3) } 24.3 \%\end{array}$ & 1.71 & 0.834 \\
\hline Total Land & $\begin{array}{l}0-25 \mathrm{da}(=1) 46.1 \% \\
26-50 \mathrm{da}(=2) 30.1 \% \\
51-75 \mathrm{da}=3) 13.7 \% \\
76-100 \mathrm{da}=4) 6.0 \% \\
101+\mathrm{da}(=5) 4.2 \%\end{array}$ & 1.91 & 1.099 \\
\hline No of Paid Workers & $\begin{array}{l}1(=1) 55.7 \% \\
2(=2) 33.6 \% \\
3(=3) 8.0 \% \\
4(=4) 1.5 \% \\
5+(=5) 1.2 \%\end{array}$ & 1.59 & 0.798 \\
\hline Production Type & $\begin{array}{l}\text { Livestock (=1) } 22.6 \% \\
\text { Crops+Livestock }(=2) 77.4 \%\end{array}$ & 1.77 & 0.419 \\
\hline
\end{tabular}

*Gross monthly minimum wage in Turkey in 2020 was 2,943Turkish Lira (TL). The net monthly wage was 2,324.70 TL

observed that providing farmers with financial support $(\mathrm{M}=3,881 \mathrm{SD}=0.578)$ can significantly positively affect.

\subsection{Measurement model}

Confirmatory Factor Analysis (CFA) was used to investigate the adequacy of the models. CFA examines the relationship between observed and latent variables. CFA makes use of the correlation and covariance matrix to explore how many groups of independent variables exist in a research model.

The values derived from the TPB model, chi-square value is 221.456 significant at 0.05 significance level, and $p=.0013$. All other fit indices for the TPB model were calculated as $\chi 2 / \mathrm{df}=1.415, \mathrm{RMSEA}=0.033$, NFI $=0.962$, 
Table 3 - Constructs/variables, measuring statements and first-order CFA analysis.

\begin{tabular}{|c|c|c|c|c|c|c|}
\hline \multicolumn{5}{|c|}{ Construct statistics } & \multicolumn{2}{|l|}{ Statements } \\
\hline Rnk & $C V$ & $\begin{array}{c}\text { Mean } \\
(S D)\end{array}$ & $\alpha$ & I. No & Item Name & $\begin{array}{l}\text { Constrcts } \\
\text { (Source) }\end{array}$ \\
\hline 1 & 0.185 & $\begin{array}{c}4.084 \\
(0.755)\end{array}$ & 0.934 & $\begin{array}{l}\text { Att1 } \\
\text { Att2 } \\
\text { Att3 } \\
\text { Att4 } \\
\text { Att5 }\end{array}$ & $\begin{array}{l}\text { Livestock manure should be disposed of by the municipality along } \\
\text { with other solid household waste. } \\
\text { Farmer's aim should be to maximise production and farm } \\
\text { efficiency, not to bother with livestock waste management. } \\
\text { In my opinion, livestock manure management is a critical issue, } \\
\text { and it is necessary to increase farmers' awareness and knowledge } \\
\text { about waste management facilities/practices. } \\
\text { Building waste disposal units on my farm will make my farm to } \\
\text { be managed more difficult. } \\
\text { Building and improving waste disposal units demands high } \\
\text { financial investment. }\end{array}$ & $\begin{array}{l}\text { Attitude } \\
\text { (Ajzen, 2012; } \\
\text { Maleksaeidi } \\
\text { and } \\
\text { Keshavarz, } \\
\text { 2019; Meijer } \\
\text { et al., 2015) }\end{array}$ \\
\hline 2 & 0.182 & $\begin{array}{c}3.963 \\
(0.720)\end{array}$ & 0.855 & $\begin{array}{l}\text { Int1 } \\
\text { Int2 } \\
\text { Int3 } \\
\text { Int4 } \\
\text { Int5 }\end{array}$ & $\begin{array}{l}\text { I am planning to improve the waste storage and disposal facilities } \\
\text { on my farm. } \\
\text { I strongly recommend other farmers to improve their on-farm } \\
\text { waste facilities. } \\
\text { I intend to improved waste storage and disposal facilities on my } \\
\text { farm. } \\
\text { I intend to encourage other farmers to improve their waste } \\
\text { disposal facilities. } \\
\text { I will expend effort in improving waste storage and disposal } \\
\text { facilities on my farm. }\end{array}$ & $\begin{array}{l}\text { Intention } \\
\text { (Ajzen, 2012; } \\
\text { Borges } \text { et } \\
\text { al., 2014; } \\
\text { Yazdanpanah } \\
\text { et al., 2014) }\end{array}$ \\
\hline 3 & 0.149 & $\begin{array}{c}3.881 \\
(0.578)\end{array}$ & 0.896 & $\begin{array}{l}\text { FS1 } \\
\text { FS2 } \\
\text { FS3 }\end{array}$ & $\begin{array}{l}\text { I am willing to dispose of my livestock manure to central disposal } \\
\text { pit if local government provides financial incentives. } \\
\text { I am willing to dispose of crop waste to common pit if local } \\
\text { government subsidise. } \\
\text { I am willing to set up a composting facility if local government } \\
\text { incentive is granted. } \\
\text { I am willing to improve my waste disposal facilities if local } \\
\text { government subsidise. }\end{array}$ & $\begin{array}{l}\text { Financial } \\
\text { Support }\end{array}$ \\
\hline 4 & 0.256 & $\begin{array}{c}3.659 \\
(0.575)\end{array}$ & 0.936 . & $\begin{array}{l}\text { SN1 } \\
\text { SN2 } \\
\text { SN3 } \\
\text { SN4 } \\
\text { SN5 }\end{array}$ & $\begin{array}{l}\text { If more farmers take their livestock manure to a central collection } \\
\text { point, I will also try to join them. } \\
\text { If the local government provides incentives, I will do my best to } \\
\text { join those efforts. } \\
\text { The way that other farmers deal with livestock manure is } \\
\text { important to me. } \\
\text { If I take my livestock manure to a central disposal unit, people } \\
\text { who are important to me will approve. } \\
\text { Most of the people in my village are willing to use the waste } \\
\text { disposal facilities provided by the municipality. Generally } \\
\text { speaking, I want to be like the other people in my village. }\end{array}$ & $\begin{array}{l}\text { Subjective } \\
\text { norms } \\
\text { (Francis } \text { et al., } \\
\text { 2004): }\end{array}$ \\
\hline 5 & 0.167 & $\begin{array}{c}2.900 \\
(0.498)\end{array}$ & 0.909 & $\begin{array}{l}\text { PBC1 } \\
\text { PBC2 } \\
\text { PBC3 } \\
\text { PBC4 } \\
\text { PBC5 }\end{array}$ & $\begin{array}{l}\text { I can manage the livestock manure waste produced on my farm in } \\
\text { a more environmentally friendly way if I want to do so. } \\
\text { Disposing of livestock manure is a complex task for me. } \\
\text { The decision to improve waste facilities/to join local government } \\
\text { initiative is under my control. } \\
\text { I have enough money and time to improve waste facilities/to take } \\
\text { livestock manure to a centrally allocated disposal unit. } \\
\text { I have the knowledge, skills, and experience to employ improved } \\
\text { waste facilities on my farm/ to take livestock manure to a centrally } \\
\text { allocated disposal unit. }\end{array}$ & $\begin{array}{l}\text { Perceived } \\
\text { Behavioural } \\
\text { Control } \\
\text { (Ajzen, 1991; } \\
\text { Francis et } \\
\text { al., 2004; } \\
\text { Maleksaeidi } \\
\text { and } \\
\text { Keshavarz, } \\
\text { 2019) }\end{array}$ \\
\hline
\end{tabular}


Table 4 - Validity and reliability indices of TPB and TPB-FS models.

\begin{tabular}{|c|c|c|c|c|c|}
\hline \multirow[b]{2}{*}{ Construct } & \multirow[b]{2}{*}{ Item } & \multicolumn{2}{|c|}{ TPB-FS Model } & \multicolumn{2}{|c|}{ TPB Model } \\
\hline & & $\begin{array}{l}\text { Validity and } \\
\text { reliability indices }\end{array}$ & $\begin{array}{l}\text { Std. loading } \\
\text { (tvalue) }\end{array}$ & $\begin{array}{l}\text { Validity and } \\
\text { reliability indices }\end{array}$ & $\begin{array}{l}\text { Std. loading } \\
\text { (tvalue) }\end{array}$ \\
\hline Attitude & $\begin{array}{l}\text { Att1 } \\
\text { Att2 } \\
\text { Att3 } \\
\text { Att4 } \\
\text { Att5 }\end{array}$ & $\begin{array}{l}\mathrm{AVE}=0.725 \\
\mathrm{CR}=0.929 \\
\mathrm{MSV}=0.264 \\
\mathrm{ASV}=0.48\end{array}$ & $\begin{array}{l}0.894(22.358) \\
0.905(21.536) \\
0.842 \text { (fixed) } \\
0.799(18.618) \\
0.977(31.604)\end{array}$ & $\begin{array}{l}\mathrm{AVE}=0.717 \\
\mathrm{CR}=0.927 \\
\mathrm{MSV}=0.289 \\
\mathrm{ASV}=0.37\end{array}$ & $\begin{array}{l}0.891 \text { (22.048) } \\
0.902 \text { (21.329) } \\
0.840 \text { (fixed) } \\
0.792 \text { (17.445) } \\
0.958(30.299)\end{array}$ \\
\hline Intention & $\begin{array}{l}\text { Int1 } \\
\text { Int2 } \\
\text { Int3 } \\
\text { Int4 } \\
\text { Int5 }\end{array}$ & $\begin{array}{l}\mathrm{AVE}=0.580 \\
\mathrm{CR}=0.847 \\
\mathrm{MSV}=0.521 \\
\mathrm{ASV}=0.17\end{array}$ & $\begin{array}{l}0.714(17.322) \\
0.737(18.276) \\
0.825(22.640) \\
0.928 \text { (fixed) } \\
0.849(18.509)\end{array}$ & $\begin{array}{l}\mathrm{AVE}=0.521 \\
\mathrm{CR}=0.843 \\
\mathrm{MSV}=0.324 \\
\mathrm{ASV}=0.12\end{array}$ & $\begin{array}{l}0.689(16.126) \\
0.755(16.852) \\
0.796(21.292) \\
0.917 \text { (fixed) } \\
0.829 \text { (19.723) }\end{array}$ \\
\hline $\begin{array}{l}\text { Financial } \\
\text { Support }\end{array}$ & $\begin{array}{l}\text { FI1 } \\
\text { FI } 2 \\
\text { FI } 3 \\
\text { FI } 4\end{array}$ & $\begin{array}{l}\mathrm{AVE}=0.671 \\
\mathrm{CR}=0.891 \\
\mathrm{MSV}=0.448 \\
\mathrm{ASV}=0.25\end{array}$ & $\begin{array}{l}0.853 \text { (fixed) } \\
0.787(17.105) \\
0.796(17.102) \\
0.786(14.888)\end{array}$ & & \\
\hline $\begin{array}{l}\text { Subjective } \\
\text { Norms }\end{array}$ & $\begin{array}{l}\text { SN1 } \\
\text { SN2 } \\
\text { SN3 } \\
\text { SN4 } \\
\text { SN5 }\end{array}$ & $\begin{array}{l}\mathrm{AVE}=0.695 \\
\mathrm{CR}=0.918 \\
\mathrm{MSV}=0.303 \\
\mathrm{ASV}=0.28\end{array}$ & $\begin{array}{l}0.887 \text { (fixed) } \\
0.860(22.173) \\
0.806(15.188) \\
0.903(20.983) \\
0.670(13.109)\end{array}$ & $\begin{array}{l}\mathrm{AVE}=0.689 \\
\mathrm{CR}=0.916 \\
\mathrm{MSV}=0.324 \\
\mathrm{ASV}=0.24\end{array}$ & $\begin{array}{l}0.808 \text { (fixed) } \\
0.767(19.753) \\
0.782(17.760) \\
0.901(16.545) \\
0.645(12.268)\end{array}$ \\
\hline $\begin{array}{l}\text { Perceived } \\
\text { Personal } \\
\text { Behaviour }\end{array}$ & $\begin{array}{l}\text { PBC1 } \\
\text { PBC2 } \\
\text { PBC3 } \\
\text { PBC4 } \\
\text { PBC5 }\end{array}$ & $\begin{array}{l}\mathrm{AVE}=0.623 \\
\mathrm{CR}=0.891 \\
\mathrm{MSV}=0.251 ; \\
\mathrm{ASV}=0.18\end{array}$ & $\begin{array}{l}0.621(9.661) \\
0.774 \text { (fixed) } \\
0.779(12.146) \\
0.697(12.764) \\
0.779(13.789)\end{array}$ & $\begin{array}{l}\mathrm{AVE}=0.632 \\
\mathrm{CR}=0.894 \\
\mathrm{MSV}: 0.257 \\
\mathrm{ASV}=0.23\end{array}$ & $\begin{array}{l}0.578(10.480) \\
0.735 \text { (fixed) } \\
0.826(14.178) \\
0.745(13.276) \\
0.743(13.734)\end{array}$ \\
\hline
\end{tabular}

$\mathrm{NNFI}=0.985, \mathrm{CFI}=0.989, \mathrm{IFI}=0.989, \mathrm{SRMR}=0.0382$, $\mathrm{GFI}=0.947, \mathrm{AGFI}=0.925$. Likewise, for the TPBFS model chi-square value is 228.587 significant at 0.05 significance level, and $\mathrm{p}=.0002$. The resulting values showed a better fit $\left(\chi_{2}\right)$ $\mathrm{df}=1.020, \mathrm{RMSEA}=0.014, \mathrm{NFI}=0,975, \mathrm{NNFI}=0,997$, $\mathrm{CFI}=0.997, \mathrm{IFI}=0.999, \mathrm{SRMR}=0,0336$; $\mathrm{GFI}=0.967$, AGFI $=0.948$ ). Thus, the CFA results of both the original and the developed model met the criteria of reliability and validity (Table 1 ).

Cronbach's alpha tests measured internal consistency. Cronbach's alpha values for each measured item varied between 0.855 to 0.936 . The Cronbach alpha coefficient of the TPB was 0.906 , while the alpha value of the TPBFS measured as 0.921 . Thus, the alpha values of both models provide accepted values. We tested the convergent validity by employing the following three criteria: standardized factor loadings equal to or greater than 0.6, average variance extracted (AVE) equal to or greater than 0.5 (Fornell and Larcker, 1981), and composite reliability (CR) equal to or greater than 0.7. Additionally, to be able to claim the discriminant validity, calculated AVE for each construct should be larger than the average shared squared variance (ASV) and also greater than the maximum shared squared variance (MSV) among all constructs in a measurement model (Hair et al., 2010). The CR values were between 0.843-0.927 for the TPB model and between 847-929 for the TPB-FS model. The analysis result shows that all $C R$ values surpassed the suggested level of 0.70 and higher Both TPB and PB-FS models are provided as AVE $\geq 0.5$, $\mathrm{CR} \geq 0.5$ and AVE $>$ ASV for each construct. All 
in all, based on the results detailed in Table 4, we can claim that model measurement provides a satisfactory indication for construct validity and reliability.

\subsection{Structural model}

The SEM analysis outcome confirmed that the TPB model set up for the research offered a satisfactory fit. The structural model confirms the direct relationship between the research's dependent variable: the farmers' intention to take animal waste to a common collection point and the independent variables (attitude, SNs and PBC). Findings indicated that the preliminary constructs included in the TPB explained $41 \%$ of the variance of the farmers' intention to take animal waste to the common disposal point.

The attitude affected the farmers' intention to adopt a new practice proposed by the municipalities on animal waste, statistically significantly and positively $(\mathrm{H} 1 \mathrm{a}: \beta=0.38 ; \mathrm{p}<0.01)$. SNs were another strong predictor of farmers' intention (H2a: $\beta=0.30 ; p<0.01)$. On the other hand, PBC had remarkably lower but statistically significant predictive power $(\mathrm{H} 3 \mathrm{a}: \beta=0.11$; $\mathrm{p}=0.04$ ). Therefore, Hypothesis 1 is supported.

The literature lacks research dedicated to animal waste using TPB. We see that similar studies on agricultural waste produce findings parallel with our study (Jiang at al., 2018; Sukhmani and Gupta, 2017). Furthermore, we extended our structural model by adding municipal financial support to be given to the farmers (TPB-FS). This allowed us to discover how the added new variable interacted with each construct in the model, what effect FS construct is on intention, and how this addition contributed to the model's development. Adding the FS variable significantly increased the explanatory power of the model. The squared multiple correlations $\left(\mathrm{R}^{2}\right)$ calculated for the TPB-FS model increased from $41 \%$ to $62 \%$. Thus the TPB-FS model increased the capability of explaining the model's variance from $41 \%$ to $62 \%$. Consequently, Hypothesis 2 is supported.

Local governments' financial support will have a very powerful positive and statistical- ly significant effect on farmers' intentions (H4: $\beta=0.56 ; p<0.01)$. The addition of the FS variable reduces the predictive power of the attitude (H1b: $\beta=0.15 ; p=0.007)$ and SNs variables (H2b: $\beta=0.16 ; p=0.003$ ) by almost half, whereas it does not affect PBC's predictive power (H3b: $\beta=0.11 ; p=0.021$ ) on intention.

The TPB-FS model was built on the assumption that FS has the direct predictor power on the intention. However, the FS variable may also have a mediatory power through the TPB model. Thus, the third model was designed, and FS's mediation effect and the significance of this effect were measured. The third research model analysis showed that FS had a strong and significant mediatory power on the farmers' behaviour (H8: $\beta=0.56 ; \mathrm{p}<0.01)$. Farmers' attitudes (H5: $\beta=0.43 ; p<0.01)$ were better predictors of the adoption of financial support provided by local governments than subjective norms (H6: $\beta=0.20 ; p=0.002)$. PBC did not have a significant effect on FS (H7: $\beta=0.04$; $\mathrm{p}=0.453$ ) variable. Thus Hypothesis 3 is partially supported. The FS variance in the third model was capable of explaining $33 \%$ of the model's variance. Bootstrap results show that the FS variable has a mediatory effect in the relationship between attitude and behaviour $(\beta=0.62 ; p<0.01)$ and in the relationship between SNs and behaviour $(\beta=0.24 ; p<0.01)$. However, financial support does not provide a mediation effect in the relationship between PBC and the farmers' behaviour $(\beta=0.03$; $\mathrm{p}<0.275$ ), $\mathrm{H} 8 \mathrm{a}$ and $\mathrm{H} 8 \mathrm{~b}$ are supported, $\mathrm{H} 8 \mathrm{c}$ is rejected, therefore Hypothesis is partially supported (Table 5).

\section{Results and discussion}

There is an increasing amount of research inquiring the underlying reasons why farmers adopt or refrain from pro-environmental attitudes (Blackstock et al., 2010; Donati et al., 2015; Karaca and Ozturk, 2018; Strazzera and Statzu, 2016). Policymakers implement various policies to ensure sustainability in agriculture. The sector continues to be the most leveraged. Guo et al. (2005) and Wheeler (2008) have emphasized the government's role in farmers' 
Table 5 - SEM estimation and hypothesis test results.

\begin{tabular}{|c|c|c|c|c|c|c|c|}
\hline & & $\begin{array}{l}\text { Unstandardized } \\
\text { path coefficient }\end{array}$ & $\begin{array}{c}\text { Standardized path } \\
\text { coefficient }\end{array}$ & $S E$. & $C R$ & $p$ & \\
\hline TPB & H1a: AT $\rightarrow$ IN & 0.325 & 0.380 & 0.049 & 6.577 & $* * *$ & \\
\hline Model (I) & $\mathrm{H} 2 \mathrm{a}: \mathrm{SN} \rightarrow \mathrm{IN}$ & 0.187 & 0.296 & 0.040 & 4.731 & $* * *$ & \\
\hline & H3a: $\mathrm{PBC} \rightarrow \mathrm{IN}$ & 0.069 & 0.114 & 0.033 & 2.091 & 0.037 & \\
\hline & $\mathrm{R}^{2}$ & 0.413 & & & & & \\
\hline TPB-FS & H1b: AT $\rightarrow$ IN & 0.129 & 0.146 & 0.048 & 2.686 & .007 & \\
\hline Model (II) & $\mathrm{H} 2 \mathrm{~b}: \mathrm{SN} \rightarrow \mathrm{IN}$ & 0.105 & 0.160 & 0.036 & 2.937 & .003 & \\
\hline & $\mathrm{H} 3 \mathrm{c}: \mathrm{PBC} \rightarrow \mathrm{IN}$ & 0.068 & 0.109 & 0.029 & 2.309 & .021 & \\
\hline & $\mathrm{H} 4: \mathrm{FI} \rightarrow \mathrm{IN}$ & 0.511 & 0.562 & 0.068 & 7.516 & $* * *$ & \\
\hline & $\mathrm{R}^{2}$ & 0.621 & & & & & \\
\hline TPB-FS & H1c: AT $\rightarrow$ IN & 0.117 & 0.132 & 0.048 & 2.428 & .015 & \\
\hline Model (III) & $\mathrm{H} 2 \mathrm{~b}: \mathrm{SN} \rightarrow \mathrm{IN}$ & 0.116 & 0.175 & 0.036 & 3.191 & .001 & \\
\hline & $\mathrm{H} 3 \mathrm{c}: \mathrm{PBC} \rightarrow \mathrm{IN}$ & 0.066 & 0.104 & 0.030 & 2.199 & .028 & \\
\hline & H5: AT $\rightarrow$ FI & 0.422 & 0.434 & 0.058 & 7.218 & $* * *$ & \\
\hline & H6: $\mathrm{SN} \rightarrow$ FI & 0.143 & 0.197 & 0.046 & 3.098 & .002 & \\
\hline & $\mathrm{H} 7: \mathrm{PBC} \rightarrow \mathrm{FI}$ & 0.029 & 0.042 & 0.039 & 2.750 & .453 & \\
\hline & H8:FI $\rightarrow$ INT & 0.514 & 0.563 & 0.068 & 7.547 & $* * *$ & \\
\hline & $\mathrm{R}^{2}(\mathrm{FI})$ & 0.331 & & & & & \\
\hline & $\mathrm{R}^{2}$ (Intention) & 0.621 & & & & & \\
\hline & H8a: $\mathrm{AT} \rightarrow \mathrm{FI} \rightarrow \mathrm{INT}$ & & 0.621 & $(0.014$ & $0.098)$ & $=0.001$ & yes \\
\hline $\begin{array}{l}\text { Moderation } \\
\text { Effect }\end{array}$ & $\mathrm{H} 8 \mathrm{~b}: \mathrm{SN} \rightarrow \mathrm{FI} \rightarrow \mathrm{INT}$ & & 0.242 & & 219) 1 & .001 & yes \\
\hline & $\mathrm{H} 8 \mathrm{c}: \mathrm{PBC} \rightarrow \mathrm{FI} \rightarrow \mathrm{INT}$ & & 0.025 & $(-0.022$ & $0.078)$ & $=0.275$ & no \\
\hline
\end{tabular}

** Correlation is significant at the 0.01 level (2-tailed), $n s$ : Not significant, Bootstrapping based on $n=2000$ subsamples.

Significance levels: $* * * p<0.01, * * p<0.05, * p<0.1$.

adoption of sustainable farming practices. Turkey's support payments range from organic agriculture, good farming practices, soil analysis, fuel, fertilizer and purchase to livestock support. Livestock support covers only animal breeding. In 2019, the MFAL provided 50\% grant support to livestock farmers who have $10-50$ bovines and 100-200 bovines. These grants were allocated for the construction/renovation of barns, the purchase of animals and the purchase of machinery, tools and equipment. As it is seen, there is no support for improving manure storage.

Article 7 of the Municipality Law 6360 states that: "Metropolitan and district municipalities can perform all kinds of activities and services to support agriculture and animal husbandry". Elias and Marsh (2020) give an example of mu- nicipal governments pursuing partnerships with peri-urban farmers and breeders to protect fertile land together, refrain ecosystem services from harmful development, reach greenhouse reduction targets and generate economic value. The partnership of Santa Clara County and the Open Space Authority for Santa Clara Valley in 2018 was successfully set up in the heart of Silicon Valley. Another example the authors cite was the California government's role in creating innovative programs to promote the protection of working landscapes and sustainable farming engagement, splitting investment costs and funding ecosystem services.

The municipalities in Turkey began to actively engage in agriculture as a result of a legal obligation. They provide support to the farmers by 
donating seeds, tiller, and fertilizer. They buy the harvest from the farmer and increase the number of farmer markets. Municipalities have also started to assist farmers in waste-related issues in line with their responsibilities in waste management. For example, Tekirdag Metropolitan Municipality is conducting a feasibility study to determine the amount of agricultural (such as grain, sunflower, corn and paddy) and animal waste and build bioenergy biogas briquettes, pellets and compost facilities. The purpose of the municipality is to recycle organic waste in the region as biomass energy instead of disposing of them to harm the environment. Antalya Metropolitan Municipality has planned to implement a recycling project aiming to reduce the farmer's production cost by collecting the greenhouse and orchards waste. Mersin Metropolitan Municipality has started the project to set up an oyster mushroom compost facility from agricultural wastes.

The use of animal waste can reduce the adverse effects of these wastes on the environment and ensure the recovery of the resource that would otherwise go idle to the economy. However, establishing compost or biogas plants requires high investment, technical knowledge and experience, and goes beyond small-scale farmers' capabilities. Therefore, such facilities are established by large companies with the inducement of local and central governments. A central collection point to be provided by local governments will help prevent the detrimental effects and in providing inputs to compost and biogas facilities.

The cooperation of farmers is essential for such an initiative to be implemented. To pursue the cooperation of farmers, financial support should be provided to them. The possible effect of providing this support on their attitudes and behaviour should be investigated and understood. The support offered should be easy for the farmer to understand and apply, and there should be no excessive paperwork. The complexity of the legislation and the late arrival of the support cause the farmers to look at such supports with suspicion.

The research result again underlines that farmers have a positive attitude in the management of wastes even tough participate in this initiative would not actually increase their yields and would even bring them additional labour and time burden. Besides, the financial support to be provided to them will significantly increase the likelihood of displaying this positive behaviour. Authors further argue that farmers altered their behaviour as a result of not only monetary but also moral values and social pressure. Since farmers live in smaller communities, they are significantly affected by information networks, such as relatives, neighbours and fellow farmers (Genius et al., 2006; Läpple and Kelley, 2013; Wollni and Andersson, 2014). Therefore, the effect of the subjective norm variable on behaviour has been observed to be close to the attitude variable. The effect of the subjective norms exceeds attitude when financial support becomes a mediatory variable.

\section{Conclusions}

This study aimed to analyze the farmers' behaviour in assessing manure waste disposal using the TPB model. We also examined the direct and moderating impact of local governments' financial support on farmers' manure handling behaviour. The TPB model created within the research framework has proven to be adequate to understand farmers' animal waste assessment behaviour. The addition of the financial support dimension increased the explanatory power of the model.

Financial subsidies are pricey and strain the limited public funds in developing countries that often face high budget deficits. Devising financial support requires determining the right price level. Farmers will be willing to collect and transport livestock manure and determine whether the price will be an acceptable input cost for a likely biogas or compost production. Examples cited, however, have shown that local government-farmer collaborations work and lead to significant progress in achieving environmental sustainability in rural and urban settlements over several years, as long as they are well designed and farmers are not overwhelmed by bureaucratic obstacles.

It is essential to note that some limitations should be considered in this study. First, the outcomes of this analysis carried out in Turkey may 
differ from other cultures and regions. The results of research conducted in different continents and countries with different levels of development may differ. This research was applied to all livestock farmers without making any distinction between dairy and fattening livestock. Farmers in these two sub-sectors may face different problems and maybe different factors affecting their behaviour. We have not taken into account whether farmers have received any other financial aid in the past, their level of satisfaction and effectiveness from those financial aids if they have received it. The satisfaction level and effectiveness of a received aid may affect the trust in the institutions that provide that aid positively or negatively. Therefore, we propose further studies to undertake a new study, including these factors. We included only the financial aid construct in the classical TPB model. However, the model can be further enriched by adding additional factors to gain more in-depth insight, such as experience with financial aids, knowledge levels about available aids and the adequacy of information received by extension agents.

Despite the limitations mentioned above, this research may inspire local and central governments, private or public institutions, policymakers and entrepreneurs who want to produce compost or biogas from animal waste. Policymakers should support local and central governments' attempts to ensure the proper disposal and re-economize of animal waste, sensitively review and update inadequate environmental processes, laws and regulatory tools, and put an end to practices that prevent businesses from adopting environmentally friendly practices. Local administrations should now be invited to participate in public environmental policies in the agriculture and agri-food sectors. Local governments need to instil environmental values in farmers' behaviour and better anticipate the legal environmental and economic factors.

\section{Supplementary data}

Supplementary data to this article can be found online at https://doi. org/ 10.17632/2r7sbwv3sk.5.

\section{References}

Ajzen I., 1985. From Intentions to Actions: A Theory of Planned Behavior. In: Kuhl J., Beckmann J. (eds.), Action Control. Berlin, Heidelberg: Springer, pp. 1139 (SSSP Springer Series in Social Psychology). https://doi.org/10.1007/978-3-642-69746-3_2.

Ajzen I., 1991. The theory of planned behaviour. Organizational Behavior and Human Decision Processes, 50(2): 179-211. https://doi.org/10.1016/07495978(91)90020-T.

Ajzen I., 2012. The theory of planned behavior. In: van Lange P.A.M., Kruglanski A.W., Higgins E.T. (eds.), Handbook of Theories of Social Psychology. London, UK: Sage Publications, Vol. 1, pp. 438459. https://doi.org/10.4135/9781446249215.n22.

Anderson J.C., Gerbing D.W., 1988. Structural equation modelling in practice: Areview and recommended twostep approach. Psychological Bulletin, 103(3): 411423. https://doi.org/10.1037/0033-2909.103.3.411.

Atilgan A., Alagoz T., Saltuk B., Erkan M., 2005. Current status and development of manure depots in animal shelters. Çukurova University Journal of Faculty of Agriculture, 20(2): 37-46.

Bagheri A., Bondoria A., Allahyarib M.S., Damalas C.A., 2019. Modeling farmers' intention to use pesticides: an expanded version of the theory of planned behaviour. Journal of Environmental Management, 248: 109291. https://doi.org/10.1016/j. jenvman.2019.109291.

Bagozzi R.P., Yi Y., 1988. On the evaluation of structural equation models. Journal of the Academy of Marketing Science, 16: 74-94. http://dx.doi. org/10.1007/BF02723327.

Blackstock K.L., Ingram J., Burton R., Brown K.M., Slee B., 2010. Understanding and influencing behaviour change by farmers to improve water quality. Science of the Total Environment, 408(23): 5631-5638. https://doi.org/10.1016/j.scitotenv.2009.04.029.

Bonadonna A., Matozzo A., Giachino C., Peira G., 2019. Farmer behaviour and perception regarding food waste and unsold food. British Food Journal, 121(1): 89-103. https://doi.org/10.1108/BFJ-122017-0727.

Borges J.A.R., Oude Lansink A.G.J.M., Marques Ribeiro C., Lutke V., 2014. Understanding farmers' intention to adopt improved natural grassland using the theory of planned behaviour. Livestock Science, 169: 163-174. http://dx.doi.org/10.1016/j. livsci.2014.09.014.

Boyaci S., Akyuz A., Kukurtcu M., 2011. Environmental pollutions caused by manure in animal 
barns and potential solutions. Journal of Agricultural Sciences Research, 4(1): 49-55.

Bursa Governorhip 2019. Bursa economic and social indicators 2018. http://www.bursa.gov.tr/ ekonomik-ve-sosyal-gostergeler. Accessed November 9, 2020.

Case S.D.C., Oelofse M., Hou Y., Oenema O., Jensen L.S., 2017. Farmer perceptions and use of organic waste products as fertilizers-a survey study of potential benefits and barriers. Agricultural Systems, 151: 84-95. http://dx.doi.org/10.1016/j.agsy.2016.11.012.

Cayir M., Atilgan A., Oz H., 2012. Examinations of manure condition from cattle barns related to water resources. Suleyman Demirel University Journal of Faculty of Agriculture, 7(2): 1-9.

Chaudhary A.K., Warner L.A., Lamm A.J., Israel G.D., Rumble J.N., Cantrell R.A., 2017. Using the theory of planned behaviour to encourage water conservation among extension clients. Journal of Agricultural Education, 58(3): 185-202. https://doi. org/10.5032/jae.2017.03185.

Cheng J., Qiao J., Chen Y., Yang Z., 2015. Nutrient loads of small-scale swine manure composting to groundwater and its prevention by covering: a case study. Environmental Science and Pollution Research, 22: 15646-15655. http://dx.doi. org/10.1007/s11356-015-4705-2.

Christensen T., Pedersen A.B., Nielsen H.O., Mørkbak M.R., Hasler B., Denver S., 2011. Determinants of farmers' willingness to participate in subsidy schemes for pesticide-free buffer zones -A choice experiment study. Ecological Economics, 70(8): 1558-1564. https://doi.org/10.1016/j. ecolecon.2011.03.021.

Daxini A., O'Donoghued C., Ryana M., Buckley C., Barnes A.P., Daly K., 2018. Which factors influence farmers' intentions to adopt nutrient management planning? Journal of Environmental Management, 224: 350-360. https://doi.org/10.1016/j. jenvman.2018.07.059.

Donati M., Menozzi D., Fioravanzi M., 2015. Understanding farmers' responses to CAP reform. New Medit, 14(3): 29-39.

Elias M., Marsh R. 2020. Innovations in agricultural and food systems sustainability in California. Case Studies in the Environment, 4(1): 1-14. https://doi. org/10.1525/cse.2019.002170.

Fornell C., Larcker D.F., 1981. Evaluating structural equation models with unobservable variables and measurement error. Journal of Marketing Research, 18(1): 39-50. https://doi.org/10.2307/3151312.

Francis J.J., Eccles M.P., Johnston M., Walker A., Grimshaw J., Foy R. et al., 2004. Constructing ques- tionnaires based on the theory planned behaviour: a manual for health researchers. University of Newcastle, UK: Centre for Health Services Research.

Genius M., Pantzios C.J., Tzouvelekas V., 2006. Information Acquisition and Adoption of Organic Farming Practices. Journal of Agricultural and Resource Economics, 31(1): 93-113.

Guo H., Jolly R.W., Zhu J., 2005. Contract farming in China: supply chain or ball chain? Paper presented at Minnesota International Economic Development Conference, University of Minnesota, April 29-30.

Gurbuz I.B., Ozkan G., 2019a. Hayvancılığın Geleceğine Eleştirel bir Bakış: Geleneksel ve Modern Hayvancılığın Karbon Ayak İzi Karşılaştırması. XIII International Balkan and Near Eastern Congress Series on Economics, Business and Management, Tekirdag, Turkey, October 5-6, pp. 294-300.

Gurbuz I.B., Ozkan G. 2019b. Consumers' knowledge, attitude and behavioural patterns towards the liquid wastes (cooking oil) in Istanbul, Turkey. Environmental Science and Pollution Research, 26(16): 16529-16536. https://doi.org/10.1007/s11356-01905078-1.

Hair J.F., Black W.C., Babin B.J., Anderson R.E. 2010. Multivariate Data Analysis, $7^{\text {th }}$ ed. Upper Saddle River, NJ: Prentice Hall.

Hennessy D.A., Wolf C.A., 2018. Asymmetric information, externalities and incentives in animal disease prevention and control. Journal of Agricultural Economics, 69(1): 226-242. https://doi. org/10.1111/1477-9552.12113.

Henseler J., Dijkstra T.K., Sarstedt M., Ringle C.M., Diamantopoulos A., Straub D.W., Ketchen D.J., Hair J.F., Hult G.T.M., Calantone R.J., 2014. Common beliefs and reality about partial least squares: Comments on Rönkkö \& Evermann (2013). Organizational Research Methods, 17(2): 182-209. https://doi.org/10.1177/1094428114526928.

Hodge I., 2013. Agri-environment policy in an era of lower government expenditure: CAP reform and conservation payments, Journal of Environmental Planning and Management, 56(2): 254-270. https:// doi.org/10.1080/09640568.2012.664103.

Jiang L., Zhang J., Wang H.H., Zhang L., He K., 2018. The impact of psychological factors on farmers' intentions to reuse agricultural biomass waste for carbon emission abatement. Journal of Cleaner Production, 189: 797-804. https://doi.org/10.1016/j. jclepro.2018.04.040.

Karaca C., Ozturk, H., 2018. An economical, energetical and environmental management of olive oil production wastes. New Medit, 17(1), 3-12. https:// doi.org/10.30682/nm1801a. 
Kline R.B., 2005. Methodology in the social sciences. Principles and practice of structural equation modelling, $2^{\text {nd }}$ ed. New York: Guilford Press.

Koca A.S., 2016. Provinces became metropolitan; villages disappeared. Dunya E-Journal, 22 June. https://www.dunya.com/gundem/iller-buyuksehiroldu-koyler-yok-oldu-haberi-320689. Accessed November 12, 2020.

Läpple D., Kelley H., 2013. Understanding the uptake of organic farming: Accounting for heterogeneities among Irish farmers. Ecological Economics, 88: 1119. https://doi.org/10.1016/j.ecolecon.2012.12.025.

MacCallum R.C., Browne M.W., Sugawara H.M., 1996. Power analysis and determination of sample size for covariance structure modeling. Psychological Methods, 1(2): 130-149. https://doi. org/10.1037/1082-989X.1.2.130.

Maleksaeidi H., Keshavarz M., 2019. What influences farmers' intentions to conserve on-farm biodiversity? An application of the theory of planned behaviour in Fars province, Iran. Global Ecology and Conservation, 20: e00698. https://doi. org/10.1016/j.gecco.2019.e00698.

Meena M.S., Kumar A., Singh K.M., Meena H.R., 2009. Farmers' attitude towards post-harvest issues of horticultural crops. Indian Research Journal of Extension Education, 9(3): 15-19.

Meijer S.S., Catacutan D., Sileshi G.W., Nieuwenhuis M., 2015. Tree planting by smallholder farmers in Malawi: Using the theory of planned behaviour to examine the relationship between attitudes and behaviour. Journal of Environmental Psychology, 43: 1-12. http://dx.doi.org/10.1016/j.jenvp.2015.05.008.

Mondal S., Haitook T., Simaraks S., 2014. Farmers' knowledge, attitude and practice toward organic vegetable cultivation in Northeast Thailand. Kasetsart Journal - Social Sciences, 35(1): 158-166.

Ntakirutimana L., Li F., Huang X., Wang S., Changbin Y.C., 2019. Green manure planting incentive measures of local authorities and farmers' perceptions of the utilization of rotation fallow for sustainable agriculture in Guangxi, China. Sustainability, 11: 2723. https://doi.org/10.3390/su11102723.

Nunnally J.C., 1978. Psychometric theory, $2^{\text {nd }}$ ed. New York: McGraw-Hill.

Official Gazette, 2012. Law on establishing metropolitan municipalities in thirteen provinces and creating twenty-six new districts and amendment of some laws and decrees. Law No: 6360. Acceptance Date: November 12, 2012. Official Gazette Date: December 6, 2012, Official Gazette No. 28489.

Pongkijvorasin S., Teerasuwannajak K.T., 2019. A study of farmer's decision and incentive scheme to reduce highland maize farming in Thailand. International Journal of Agricultural Sustainability, 17(3): 257-270. https://doi.org/10.1080/14735903. 2019.1631681.

Power E.F., Kelly D.L., Stout J.C., 2013. Impacts of organic and conventional dairy farmer attitude, behaviour and knowledge on farm biodiversity in Ireland. Journal for Nature Conservation, 21(5): 272-278. https://doi.org/10.1016/j.jnc.2013.02.002. Pröbstl-Haider U., Mostegl N.M., Kelemen-Finan J., Haider W., Formayer H., Kantelhardt J., Moser T., Kapfer M., Trenholm R., 2016. Farmers' preferences for future agricultural land use under the consideration of climate change. Environmental Management, 58(3): 446-464. https://doi.org/10.1007/ s00267-016-0720-4.

Rezaei R., Mianajia S., Ganjloob A., 2018. Factors affecting farmers' intention to engage in onfarm food safety practices in Iran: Extending the Theory of planned behaviour. Journal of Rural Studies, 60: 152-166. https://doi.org/10.1016/j. jrurstud.2018.04.005.

Rezaei R., Safa L., Damalasb C.A., Ganjkhanloo M.M., 2019. Drivers of farmers' intention to use integrated pest management: Integrating Theory of planned behaviour and norm activation model. Journal of Environmental Management, 236: 328-339. https://doi.org/10.1016/j.jenvman.2019.01.097.

Simha P., Lalander C., Vinnerås B., Ganesapillai M., 2017. Farmer attitudes and perceptions to the re-use of fertilizer products from resource-oriented sanitation systems - The case of Vellore, South India. Science of Total Environment, 581-582: 885-896. https://doi.org/10.1016/j.scitotenv.2017.01.044.

Strazzera E., Statzu V., 2016. A choice experiment study on the farmers' attitudes toward biogas and waste reuse in a nitrates vulnerable zone. Paper presented at the $5^{\text {th }}$ AIEAA (Italian Association of Agricultural and Applied Economics) Conference "The changing role of regulation in the bio-based economy", June 16-17, Bologna, Italy.

Sukhmani, Gupta M., 2017. Using theory of planned behaviour in investigating agricultural waste management: Survey evidence from Northern India. Vilakshan XIMB Journal of Management, 14(2): 39-52.

Tarmakbir (The Turkish Association of Agricultural Machinery \& Equipment Manufacturers), 2019. Turkey agricultural machinery sector. Sector report. http://www.tarmakbir.org/haberler/tarmakbirsekrap.pdf. Accessed November 3, 2020.

Thu V.H., Tran D., Goto D., Kawata K., 2019. Pecuniary versus non-pecuniary interventions to influence 
farmers' behaviour: evidence from field experiment in Vietnam, Hiroshima University, Graduate School for International Development and Cooperation (IDEC), IDEC DP ${ }^{2}$ Series, Vol. 8, No. 9, pp. 1-33. http://doi.org/10.15027/47407.

Wang J., Yang C., Ma W., Tang J., 2020. Risk preference, trust, and willingness-to-accept subsidies for pro-environmental production: an investigation of hog farmers in China. Environmental Economics and Policy Studies, 22: 405-431. https://doi. org/10.1007/s10018-020-00262-x.

Wang Y., Liang J., Yang J., Ma X., Li X., Wu J. et al., 2019. Analysis of the environmental behaviour of farmers for non-point source pollution control and management: An integration of the theory of planned behaviour and the protection motivation theory. Journal of Environmental Management, 237: 15-23. https://doi.org/10.1016/j.jenvman.2019.02.070.

Wheeler S.A., 2008. The barriers to further adoption of organic farming and genetic engineering in Australia: Views of agricultural professionals and their information sources. Renewable Agriculture Food Systems, 23(2): 161-170. http://dx.doi.org/10.1017/ S1742170507002128.

Wollni M., Andersson C., 2014. Spatial patterns of organic agriculture adoption: Evidence from Hon- duras. Ecological Economics, 97: 120-128. http:// dx.doi.org/10.1016/j. ecolecon.2013.11.010.

Xiong K., Kong F., 2017. The analysis of farmers' willingness to accept and its influencing factors for ecological compensation of Poyang Lake Wetland. Procedia Engineering, 174: 835-842. http://dx.doi. org/10.1016/j.proeng.2017.01.230.

Yamane T., 1967. Statistics: an introductory analysis, $2^{\text {nd }}$ ed. New York: Harper and Row.

Yavuz O., Gürbüz I.B., 2001, Bursa İli Karacabey İlçesi'nde arazi toplulaştırması yapılan köylerde sosyo-ekonomik yap 1 ve yeniliklerin benimsenmesi. Uludağ Üniversitesi Ziraat Fakültesi Bilimsel Araştırmalar ve İncelemeler Serisi No:24, Bursa.

Yazdanpanah M., Hayati D., Hochrainer-Stigler S., Zamani G.H., 2014. Understanding farmers' intention and behaviour regarding water conservation in the Middle-East and North Africa: a case study in Iran. Journal of Environmental Management, 135: 63-72. http://dx.doi.org/10.1016/j.jenvman.2014.01.016.

YCE (Yenisehir Commodity Exchange), 2017. Agricultural statistics of Yenisehir, 2016. First 6 monthly figures. http://yenisehirtb.org.tr. Accessed November 8, 2020. 